Asia Proceedings of Social Sciences

(APSS)

www.readersinsight.net/APSS

\title{
Online Food Delivery Service Quality: Does Personal Innovativeness Matter?
}

\author{
Yusra* \\ Universiti Kebangsaan Malaysia, Gradutate School of business (UKM-GSB), \\ Malaysia \\ Sekolah Tinggi Ilmu Ekonomi (STIE) Sabang, Banda Aceh, \\ Indonesia

\section{Arawati Agus} \\ Universiti Kebangsaan Malaysia, Gradutate School of business (UKM-GSB), \\ Malaysia
}

*Corrosponding author's Email: yusrahusainy@gmail.com 


\section{Research High Iight s}

The emergent of online food delivery (OFD) industry is valued as a new channel in food industry in order to grab more sales and shares and has promoted the competitiveness among the OFD players. Therefore, a sufficient understanding of the nature of the online service industry is very important for service providers in this emerging market.

This study attempts to discover the characteristics and necessities of this online service. Using adapted questionnaire from M-S-QUAL (Huang et al., 2015), this study aims to examine the relationships between customers perceived service quality of online food delivery (OFD) and its influence on customer satisfaction and loyalty, moderated by personal innovativeness.

The study proposed six hypothesis and results indicated the positive relationships between service quality, customer satisfaction, and customer loyalty. Whilst customer satisfaction partially mediates service quality and customer loyalty, personal innovativeness has a negative moderating effect on customer satisfaction and customer loyalty.

\section{Research Objectives}

Though the online service industry has become popular, the nature of this market is weakly understood (Cheow et al., 2017). However, delivering excellent service in any service industry is essential in order to gain a competitive advantage (Caro and García, 2007). Therefore, how the customer perceived this online service must be fully understood by service providers and it requires the OFD service quality measuring (Huang et al., 2015). Thus, evaluating users' perceived service quality to achieve customer loyalty is very essential for firms to survive in this competitive market.

The scale utilization and exploration of service quality measurement, especially in the OFD industry is limited (Heo et al., 2017). Mostly, prior studies investigate the link between customer attitude toward the service and little addressed the customers' behavior response (Cheow et al., 2017). Further, the presence of internal characteristics, such as personal innovativeness in customers response of post-adoption of M-commerce is also limited (Bilgihan et al., 2016). Therefore, this study attempts to address this issue and fulfill the gap by examining the effect of OFD service quality on customer satisfaction and loyalty, and the personal innovativeness role to moderate the linkages of customer satisfaction-loyalty and service quality-loyalty. 


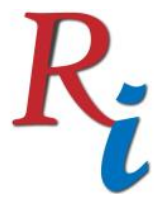

Asia Proceedings of Social Sciences

(APSS)

www.readersinsight.net/APSS

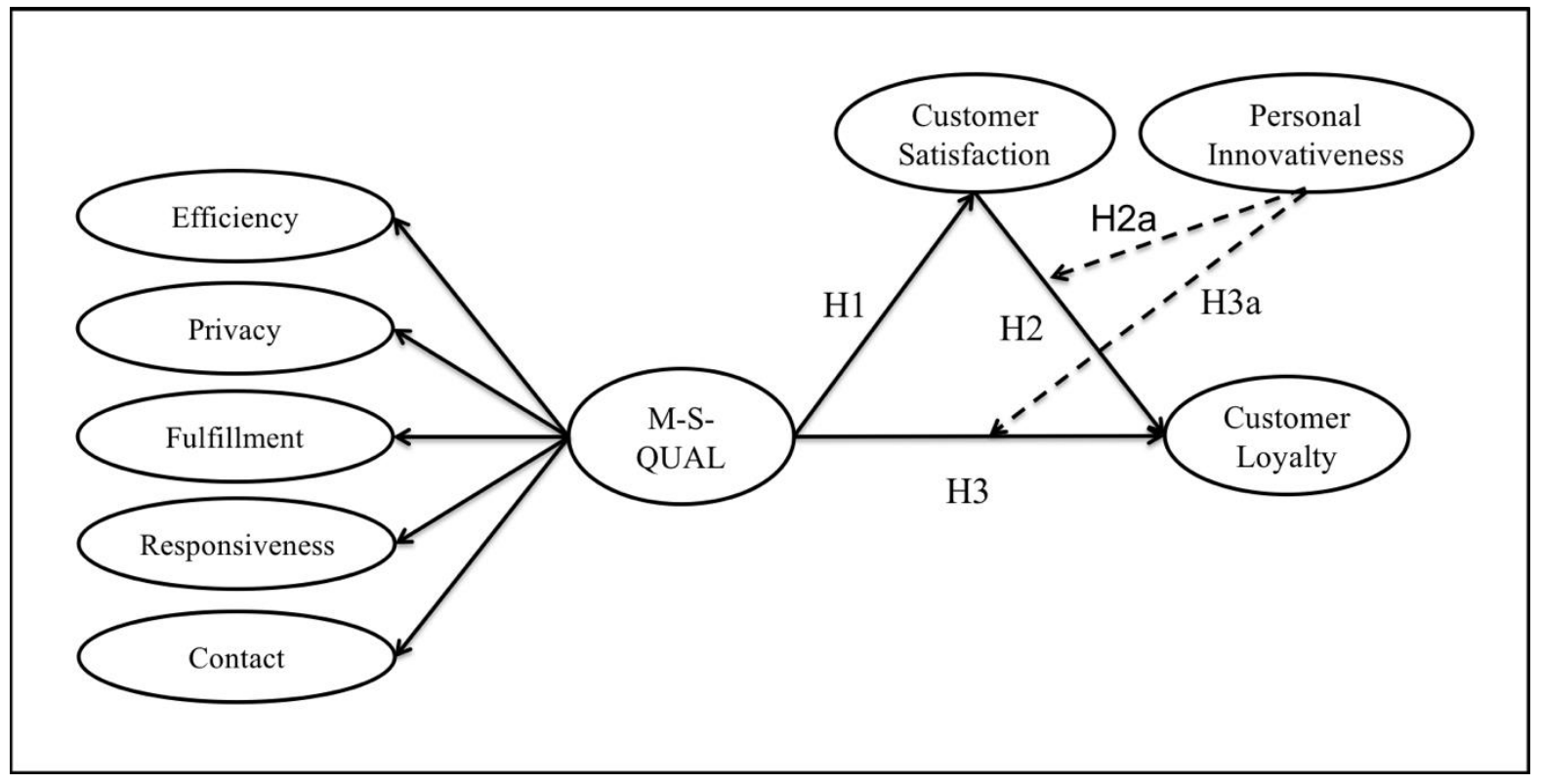

Research Model

\section{Methodology}

The questionnaire designed was adapted from existing scale, and comprised of three sections, M-S-Qual, (Contact, Responsiveness, Efficiency, Privacy, and Fulfillment), Customer Response (Personal Innovativeness, Customer Satisfaction, and Customer Loyalty) and Demographic Information. Similarly, items used are mostly from prior studies. Service quality was operationalized using a reflective model of Five dimensions which has three to four items. Three items were used to measure Personal Innovativeness (Agarwal and Prasad, 1998), three items for Customer Satisfaction (Oliver, 1993), and four items for customer loyalty (Dick and Basu, 1994). Likert Scale ranging from 1 (strongly disagree) to 7 (strongly agree) was used. Nonprobability sampling was employed and 158 usable responses were received than analyzed.

The hypothesis was analyzed using Hierarchical Moderated Regression. The mediation effect was tested using regression analysis (Agus, 2010), while the moderation effect of personal innovativeness was tested using Moderated Regression Analysis (Agus, 2008). Multicollinearity test was also conducted due to the need to check whether two or more variables in the regression model are highly correlated. The result showed that the multicollinearity problem was not serious, so that the correlation and regression analyses may proceed. 


\section{Results}

The results indicated that service quality variables showed high associations among them and so with the relationship with customer satisfaction and customer loyalty. The mediation analysis showed that after involving customer satisfaction in the link between service quality and customer loyalty, although significant, the beta value of service quality decreased from 0.505 to 0.468 . This means that customer satisfaction plays the partial mediation role and thus, the mediation hypothesis was supported.

In addition, the moderation regression analysis (MRA) was used to analyze the moderation effect of personal innovativeness. The result indicated that the relationship between customer satisfaction and loyalty $(\beta=-0.173 ; p<0.05)$ was moderated negatively by personal innovativeness. It implied that when personal innovativeness was at a higher level, customer satisfaction had a lower effect on customer loyalty. However, the result showed that the moderation role of personal innovativeness on customer satisfaction-loyalty link was significant and therefore, moderation hypothesis for the satisfaction-loyalty link was supported. In contrast, the result also indicated that personal innovativeness was not significant $(\beta=$ 0.080). Therefore the moderation hypothesis on service quality-loyalty link was rejected.

\section{Findings}

The findings suggest that service quality are positively related to customer loyalty. Dimension responsiveness has an utmost correlation with loyalty. Thus to attain customer loyalty, the firms must pay attention to deliver the service responsively. It also discovers that personal innovativeness moderates the satisfaction and loyalty link negatively. It infers that the customer satisfaction-loyalty relationship will be decreased for users with high personal innovativeness due to the majority of online food service are young people who are generally engaged with high-tech behavior. Thus, the online food service firms need to improve their service continuously by considering consumers' personal innovativeness. 


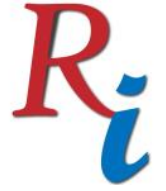

\section{Asia Proceedings of Social Sciences \\ (APSS) \\ www.readersinsight.net/APSS}

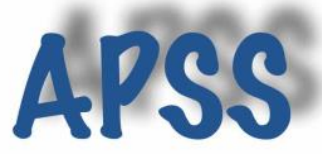

\section{References}

Agarwal, R., Prasad, J., 1998. A Conceptual and Operational Definition of Personal Innovativeness in the Domain of Information Technology. Inf. Syst. Res. 9, 204-215. https://doi.org/10.1287/isre.9.2.204.

Agus, A. (2010). The importance of new technology and innovation in SCM in enhancing production performance and product quality performance: an investigation on mediating effect. Global Review of Business and Economic Research, 6(2), 1938.

Agus, A (2008). Quality Management Profitability Linkage: Does The Length of QM Adoption Act as The Moderating Variable? International Journal of Management Studies.Vol. 15(Sept.08), 1-23. ISSN 0127-8983.

Bilgihan, A., Kandampully, J., Zhang, T. (Christina), 2016. Towards a unified customer experience in online shopping environments: Antecedents and outcomes. Int. J. Qual. Serv. Sci. 8, 101-119. https://doi.org/http://dx.doi.org/10.1108/MRR-092015-0216.

Caro, L.M., García, J.A.M., 2007. Measuring perceived service quality in urgent transport service. J. Retail. Consum. Serv. 14, 60-72. https://doi.org/10.1016/j.jretconser.2006.04.001.

Cheow, V., Yeo, S., Goh, S., Rezaei, S., 2017. Consumer experiences, attitude and behavioral intention toward online food delivery (OFD) services. J. Retail. Consum. Serv. 35, 150-162. https://doi.org/10.1016/j.jretconser.2016.12.013.

Dick, A.S., Basu, K., 1994. Customer Loyalty: Toward an Integrated Conceptual Framework. J. Acad. Mark. Sci. 22, 99-113. https://doi.org/10.1177/0092070394222001.

Heo, J., Lim, C., Kim, K., 2017. Scales for measuring mobile service quality: a literature review and identification of key dimensions. Int. J. Serv. Oper. Manag. 27, 524-548.

Huang, E.Y., Lin, S.-W., Fan, Y.-C., 2015. M-S-QUAL: Mobile service quality measurement. Electron. Commer. Res. Appl. 14, 126-142. https://doi.org/10.1016/j.elerap.2015.01.003.

Oliver, R.L., 1993. Cognitive, Affective, and Attribute Bases of the Satisfaction Response. J. Consum. Res. 20, 418-430. https://doi.org/10.1086/209358. 